\title{
RISK FACTORS OF HIV-1 VERTICAL TRANSMISSION (VT) AND THE INFLUENCE OF ANTIRETROVIRAL THERAPY (ART) IN PREGNANCY OUTCOME
}

Maria F.M. BARRAL, Gisele R. de OLIVEIRA, Rubens C. LOBATO, Raul A. MENDOZA-SASSI, Ana M.B. MARTÍNEZ \& Carla V. GONÇALVES

\begin{abstract}
SUMMARY
In the absence of intervention, the rate of vertical transmission of HIV can range from 15-45\%. With the inclusion of antiretroviral drugs during pregnancy and the choice of delivery route this amounts to less than $2 \%$. However ARV use during pregnancy has generated several questions regarding the adverse effects of the gestational and neonatal outcome. This study aims to analyze the risk factors for vertical transmission of HIV-1 seropositive pregnant women living in Rio Grande and the influence of the use of ARVs in pregnancy outcome. Among the 262 pregnant women studied the rate of vertical transmission of HIV was found to be $3.8 \%$. Regarding the VT, there was a lower risk of transmission when antiretroviral drugs were used and prenatal care was conducted at the referral service. However, the use of ART did not influence the outcome of pregnancy. However, initiation of prenatal care after the first trimester had an influence on low birth weight, as well as performance of less than six visits increased the risk of prematurity. Therefore, the risk factors analyzed in this study appear to be related to the realization of inadequate pre-natal and maternal behavior.
\end{abstract}

KEYWORDS: HIV; Infectious Disease Transmission; Vertical; Antiretroviral Therapy; Pregnancy outcomes.

\section{INTRODUCTION}

According to UNAIDS, 34 million people are infected with HIV worldwide. Among them, 30 million are adults and 16.8 million women ${ }^{27}$. In Brazil, from 1980 to June 2011 608,230 cases of Aids were reported and over the past 12 years a stabilization of the incidence rates has been observed ${ }^{3}$. In 2010, the sex ratio was 1.7 new cases in men to one case in women, $71 \%$ of infected women are of reproductive age, with a prevalence of $0.4 \%$ of infected pregnant women ${ }^{2,3}$.

In the absence of intervention, the rates of HIV transmission during pregnancy, labor or breastfeeding vary from $15-45 \%$. Related to maternalto-child transmission (MTCT), 35\% occur during pregnancy, $65 \%$ in the peripartum and the risk of transmission through breastfeeding varies from $7 \%$ to $22 \%$. Besides obstetric and neonatal variables, maternal variables such as viral load, advanced disease, co-infections, delay or non-use of antiretroviral (ARV) at the beginning or during pregnancy influence risk of HIV MTCT ${ }^{5,18}$.

Vertical HIV transmission (VT) rates can be reduced to levels below $2 \%$ if women living with HIV have a suitable attendance during pregnancy with the use of ARV and reduce of the viral load (VL) ${ }^{6}$. In Brazil between 1980 and 2011 there were 14,127 cases of Aids in children under five. Over the last 12 years a $49.1 \%$ reduction in the absolute number of cases and $40.7 \%$ in the incidence rate $^{3}$ was observed. However, a multicenter study conducted by the Brazilian Society of Pediatrics in 2004 showed that the rate of HIV MTCT in Brazil was 6.8\% .

There are still several barriers to effective prevention of perinatal transmission of HIV both related to female behavioral characteristics, as well as the quality of clinical services provided to them ${ }^{8,10,24}$. Although the main and the most effective way to reduce to VL, use of ART during pregnancy has generated conflicting data about possible adverse effects to the neonate ${ }^{7}$, such as: preterm delivery ${ }^{1,17}$, low birth weight ${ }^{22}$, a decrease in neurological function ${ }^{28}$, and low Apgar scores ${ }^{1}$. However, to date, there is no consensus on the association between antiretroviral drugs used by women during pregnancy and their consequences. Until now there is no sufficient evidence to support that the combined use of ARV has a negative association with pregnancy outcome $e^{1,7,8,10,17,22,28}$.

The current study aimed to analyze the risk factors associated with vertical transmission of pregnant HIV-infected women in the city of Rio Grande and the influence of ART in pregnancy outcome such as prematurity, Apgar score and low birth weight.

\section{MATERIAL AND METHODS}

This study was conducted in Rio Grande, located in the southern coastal plain of Rio Grande do Sul, Brazil. The primary health care system is composed of 32 primary care units (PCU), and two general hospitals.

Faculdade de Medicina, Universidade Federal de Rio Grande, Rio Grande, RS, Brazil.

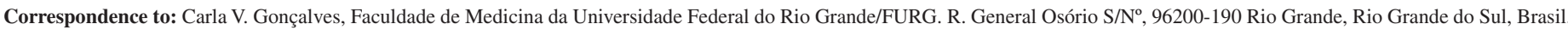
Phone: + 55.53.3233-8842. E-mail: carlavg@brturbo.com.br 


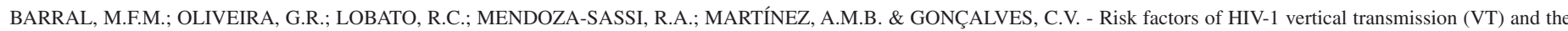
influence of antiretroviral therapy (ART) in pregnancy outcome. Rev. Inst. Med. Trop. Sao Paulo, 56(2): 133-8, 2014.

Health care for people living with HIV is offered by a specialized unit at the University Hospital Miguel Riet Correa Junior (HU-FURG). In 2003, a specific unit for seropositive pregnant women was created. Every patient has a medical record with information from ongoing prenatal, delivery and HIV MTCT. This cohort study included all pregnant women that attended the HU-FURG between July 2003 and July 2007. This endpoint date was chosen because until this period there were 95 women using Biovir $^{\circledR}$ and Nelfinavir ${ }^{\circledR}$ and the same number using Biovir ${ }^{\circledR}$ and Kaletra ${ }^{\circledR}$. The study was submitted and approved by the Ethical Committee of FURG (23116001368/2003-44 protocol). All procedures were carried out in accordance with the guidelines of the Helsinki Declaration.

The independent variables measured were: maternal age, years of schooling, number of pregnancies, parity, trimester of prenatal care initiation, number of prenatal visits, location of prenatal care (HU-FURG, other facilities, or no prenatal care), type of delivery, fasting glucose in the first or third trimester $(\geq 86 \mathrm{mg} / \mathrm{dL}), \mathrm{CD} 4+\geq 350$ count and viral load of the mother ( $\geq 1000$ copies).

An aliquot of blood was collected from all pregnant women in the thirty fourth week of gestation for viral load quantification and CD4+T lymphocytes count. The use of ARV was categorized by time in two groups (cutoff $9 / 10$ weeks). The type of ARV exposure was classified as: no use, use of Biovir ${ }^{\circledR}$ and Nelfinavir ${ }^{\circledR}$, Kaletra $^{\circledR}$ and Biovir ${ }^{\circledR}$, other ARV. Outcomes studied were: birth weight $\leq 2500 \mathrm{~g}$, fifth minute Apgar score $\leq 7$; delivery at less than 37 weeks of gestation and HIV VT.

Status of viral infection of the newborn and time of transmission was determined by the technique of Polymerase Chain Reaction (PCR) from pro-viral DNA extracted (commercial kit $®$ Illustra blood genomic Prep Mini Spin, GE Healthcare () from the first blood collection (24/48 hours), and at 30 and 60 days after birth.

Multivariate analysis was based on an analysis model using Poisson regression with robust adjustment of variance. After calculating prevalence ratios (PR) and their respective confidence intervals of $95 \%$ $(95 \% \mathrm{CI})$, variables that had a $p$-value $\leq 0.20$ in the bivariate analysis were included in the model. For the birth weight $\leq 2500 \mathrm{~g}$ outcome the variables included were: number of births, start of prenatal care trimester, and time of use of ARV. Adjusted analysis of Apgar score $\leq 7$ at the fifth minute included: maternal age and schooling years, number of prenatal care visits, site of prenatal care, fasting glucose, viral load, ARV use and time of ART. For pre-term birth $\leq 37$ weeks the following variables were analyzed: number of prenatal care visits, fasting glucose, and use of ARV. VT outcome was adjusted for: location of prenatal care, delivery type, CD4, viral load, time and use of ARV. The Wald test was used for statistical analysis and a $p$-value equal to or less than 0.05 of a two-tailed test was considered as significant.

\section{RESULTS}

The study included a total of 262 women with a mean age of 27 years $(\mathrm{SD} \pm 6.24) .68 .7 \%$ had four or less years of schooling and the number of pregnancies was on average $2.58(\mathrm{SD} \pm 2.21)$ with a parity of $2.09(\mathrm{SD} \pm 1.82)$.

The location of prenatal care was HU- FURG in $83.5 \%$ of cases, onset of prenatal care was on average 16 weeks of pregnancy, carrying around five visits each. Type of delivery was cesarean section in $61.5 \%$ of cases. Average weight of newborns was $2894 \mathrm{~g}$ and Apgar score at five minutes was 9 . Delivery was on average at 40 weeks of gestation. Regarding to the HIV status, the mean of CD4 + T cells was $574 \mathrm{cel} /$ $\mathrm{uL}$, the viral load was 10,603 copies/mL at 34 weeks of pregnancy and time of use of ARV was 16 weeks ( $\mathrm{SD} \pm 2.42$ ).

Table 1 shows the results of the prevalence ratio (PR) and their Confidence Interval $(95 \% \mathrm{CI})$. None of the studied factors showed significant association with the outcomes low birth weight and preterm birth. For the outcome fifth minute Apgar $\leq 7$, women who had less than five visits had a PR 2.18 (1.08 to 4.40) and those with fasting glucose $\geq$ $86 \mathrm{mg} / \mathrm{dL}$ had PR of 2.42 (1.26 to 4.63). On the other hand, a lower risk of low Apgar score was observed (PR 0.47; CI: 0.26-1.66) in infants born from pregnant women with longer use of ARV ( $\geq 10$ weeks).

From the 262 pregnant women, 10 (3.8\%) transmitted HIV to the newborns. In the bivariate analysis those with three or more pregnancies had an increased risk of virus transmission $(p=0.05)$. The prenatal location also showed a significant association with the risk of MTCT, when held in a location other than the University Hospital (PR 9.37; 95\% CI: 2.51 to 34.9) and in case of lack of prenatal (PR 2.90; CI: 0.5914.24). Furthermore, maternal viral load $\geq 1000$ was associated with a higher prevalence ratio (PR: 4.98; CI: 1.32-18.7) of HIV transmission to the newborn. The non-use of ARV was also related to increased risk of transmission (RP 12.9 $p=0.003$ ), the use of Biovir ${ }^{\circledR}$ and Nelfinavir ${ }^{\circledR}$ had a prevalence rate increased by three times (PR $3.0 p=0.003)$ compared to the use of Biovir ${ }^{\circledR}$ and Kaletra ${ }^{\circledR}$.

In the multivariate analysis (Table 2), after adjustment for selected variables from the bivariate analysis, it was observed that low birth weight $(\leq 2500 \mathrm{~g})$ had a higher probability of occurring when the start of prenatal care occurred in the $3^{\text {rd }}$ trimester (PR 1.07; CI: 1.01-1.14). Regarding the pre-term birth ( $\leq 37$ weeks), five or less visits had a higher probability of outcome (PR1.08; CI: 1.02-1.15). Finally, association of HIV VT with the use of ARV remained significant, with use of Biovir® and Kaletra ${ }^{\circledR}$ featuring a lower likelihood of outcome (PR 0.09; CI: 0.01-0.73), and prenatal location losing statistical significance.

\section{DISCUSSION}

The present study showed that undesirable pregnancy outcomes in women with HIV was associated to variables related to prenatal care and that VT was lower with use of Biovir ${ }^{\circledR}$ and Kaletra ${ }^{\circledR}$ and when prenatal care was taken under a specialized center. Among possible limitations is the fact that although HU-FURG is the only referral center for pregnant HIV-infected women of Rio Grande, some cases of prenatal care and delivery might have happened outside this service. Thus, pregnant women who had labor outside HU-FURG were lost in this study. Data from women who had their pregnancy monitoring outside HU-FURG, but delivery performed in this hospital, were registered in our system retroactively to childbirth.

Currently, Aids is a major public health problem worldwide. Clinical status of pregnant HIV-infected women has improved considerably with the introduction of ART. This resulted in decreased rates of HIV MTCT ${ }^{6,10,23,25}$. Nonetheless, studies have reported that despite the benefits of ART during pregnancy, some women exposed 


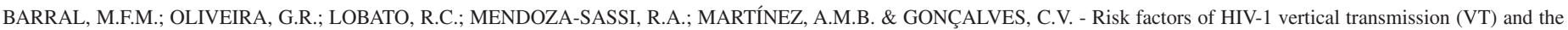
influence of antiretroviral therapy (ART) in pregnancy outcome. Rev. Inst. Med. Trop. Sao Paulo, 56(2): 133-8, 2014.

Table 1

Adverse pregnancy outcome factors associated with HIV-infected women

\begin{tabular}{|c|c|c|c|c|c|c|c|c|}
\hline \multirow{2}{*}{ Variable } & \multicolumn{2}{|c|}{ Weight $\leq 2500 \mathrm{~g}$} & \multicolumn{2}{|c|}{ Apgar $\leq 7$} & \multicolumn{2}{|c|}{ Delivery before $\leq 37$ weeks } & \multicolumn{2}{|c|}{ HIV vertical transmission } \\
\hline & $\mathrm{N}(\%)$ & $\operatorname{PR}\left({ }_{95 \% \mathrm{CI}}\right)$ & $\mathrm{N}(\%)$ & $\operatorname{PR}\left({ }_{95 \% \mathrm{CI}}\right)$ & $\mathrm{N}(\%)$ & $\operatorname{PR}\left({ }_{95 \% \mathrm{CI}}\right)$ & $\mathrm{N}(\%)$ & $\operatorname{PR}\left({ }_{95 \% \mathrm{CI}}\right)$ \\
\hline Age (years) & & $p=0.29$ & & $p=0.14$ & & $p=0.65$ & & $p=0.52$ \\
\hline 30 or more & $15(19.5)$ & 1.0 & $16(24.6)$ & 1.0 & $19(24.7)$ & 1.0 & $4(4.9)$ & 1.0 \\
\hline 20 to 29 & $26(19.1)$ & $0.37(0.09-1.50)$ & $16(13.9)$ & $0.57(0.30-1.05)$ & $26(19.3)$ & $0.78(0.46-1.31)$ & $4(2.8)$ & $0.56(0.14-2.17)$ \\
\hline 19 or less & $2(7.1)$ & $0.98(0.55-1.74)$ & $6(25.0)$ & $1.02(0.45-2.29)$ & $6(21.4)$ & $0.07(0.39-1.95)$ & $2(6.5)$ & $1.31(0.25-6.78)$ \\
\hline Schooling (years) & & $p=0.98$ & & $p=\mathbf{0 . 1 0}$ & & $p=0.75$ & & $p=0.88$ \\
\hline 5 years or more & $17(13.9)$ & 1.0 & $4(8.2)$ & 1.0 & $11(19.3)$ & 1.0 & $7(5.5)$ & 1.0 \\
\hline 4 years or less & $8(14.0)$ & $0.99(0.46-2.16)$ & $18(18.4)$ & $2.25(0.81-6.29)$ & $21(17.4)$ & $0.90(0.47-1.74)$ & $3(5.0)$ & $1.10(0.30-4.12)$ \\
\hline Pregnancies & & $p=0.57$ & & $p=0.82$ & & $p=0.95$ & & $p=0.05$ \\
\hline One & $6(12.5)$ & 1.0 & $6(13.3)$ & 1.0 & $10(20.8)$ & 1.0 & $0(0.0)$ & 1.0 \\
\hline Two & $10(18.5)$ & $1.48(0.58-3.77)$ & $8(18.2)$ & $1.36(0.52-3.61)$ & $10(18.5)$ & $0.89(0.41-1.95)$ & $2(3.6)$ & ---- \\
\hline 3 or more & $17(19.5)$ & $1.56(0.66-3.70)$ & $11(15.9)$ & $1.20(0.48-3.00)$ & $17(19.8)$ & $0.95(0.47-1.90)$ & $8(8.9)$ & ----- \\
\hline Parity & & $p=0.15$ & & $p=\mathbf{0 . 7 0}$ & & $p=0.29$ & & $p=0.60$ \\
\hline Pimiparous & 8 (11.9) & 1.0 & $10(18.2)$ & 1.0 & $11(16.4)$ & 1.0 & $3(4.1)$ & 1.0 \\
\hline Multiparous & $24(20.2)$ & $1.69(0.00-3.55)$ & $16(15.8)$ & $0.87(0.42-1.79)$ & $27(22.9)$ & $1.39(0.74-2.63)$ & $7(5.7)$ & $1.42(0.38-5.31)$ \\
\hline Start of prenatal care & & $p=0.07$ & & $p=0.71$ & & $p=0.41$ & & $p=0.54$ \\
\hline $1^{\circ}$ trimester & $17(19.5)$ & 1.0 & $11(13.8)$ & 1.0 & $17(19.5)$ & 1.0 & $4(4.3)$ & 1.0 \\
\hline $2^{\circ}$ trimester & $18(22.0)$ & $1.12(0.62-2.03)$ & $12(16.4)$ & $1.20(0.56-2.54)$ & $21(25.6)$ & $1.31(0.75-2.30)$ & $3(3.3)$ & $0.77(0.18-3.37)$ \\
\hline $3^{\circ}$ trimester & $2(5.3)$ & $0.27(0.07-1.11)$ & $6(20.0)$ & $1.45(0.59-3.58)$ & $6(15.8)$ & $0.81(0.35-1.89)$ & $3(7.7)$ & $1.79(0.42-7.62)$ \\
\hline Number of visits & & $p=0.26$ & & $p=0.02$ & & $p=0.16$ & & $p=0.54$ \\
\hline$\geq 6$ visits & $16(15.0)$ & 1.0 & $10(10.3)$ & 1.0 & $15(14.0)$ & 1.0 & $4(3.6)$ & 1.0 \\
\hline$\leq 5$ visits & $22(20.8)$ & $0.99(0.46-2.16)$ & $20(22.5)$ & $2.18(1.08-4.40)$ & $29(27.4)$ & $1.95(1.11-3.43)$ & $6(5.2)$ & $1.46(0.42-5.04)$ \\
\hline Prenatal care location & & $p=0.98$ & & $p=0.07$ & & $p=0.61$ & & $p=0.001$ \\
\hline University Hospital & $35(17.4)$ & 1.0 & $31(17.0)$ & 1.0 & $43(21.4)$ & 1.0 & $5(2.5)$ & 1.0 \\
\hline Other facilities & $3(30.0)$ & $1.72(0.64-4.65)$ & $0(0.0)$ & --- & $1(10.0)$ & $0.47(0.07-3.06)$ & $3(23.1)$ & $9.37(2.51-34.9)$ \\
\hline No prenatal care & $4(16.0)$ & $0.92(0.36-2.37)$ & $8(47.1)$ & $2.76(1.52-5.02)$ & $6(25.0)$ & $1.17(0.56-2.45)$ & $2(7.1)$ & $2.90(0.59-14.24)$ \\
\hline Type of delivery & & $p=0.87$ & & $p=0.22$ & & $p=0.42$ & & $p=0.16$ \\
\hline Cesarean section & $26(17.4)$ & 1.0 & $22(16.7)$ & 1.0 & $34(22.8)$ & 1.0 & $4(2.7)$ & 1.0 \\
\hline Vaginal & $17(18.3)$ & $1.05(0.60-1.82)$ & $17(23.6)$ & $1.42(0.81-2.49)$ & $17(18.5)$ & $0.81(0.48-1.36)$ & $6(6.3)$ & $1.32(0.69-8.17)$ \\
\hline Fasting glucose & & $p=0.48$ & & $p=0.04$ & & $p=0.10$ & & $p=0.43$ \\
\hline$\leq 85 \mathrm{mg} / \mathrm{dL}$ & $31(18.9)$ & 1.0 & $20(13.8)$ & 1.0 & $32(19.5)$ & 1.0 & $7(4.0)$ & 1.0 \\
\hline$\geq 86 \mathrm{mg} / \mathrm{dL}$ & $6(14.3)$ & $0.76(0.34-1.65)$ & $10(27.8)$ & $2.42(1.26-4.63)$ & $13(31.0)$ & $1.59(0.92-2.74)$ & $3(6.7)$ & $1.68(0.45-6.23)$ \\
\hline CD4 & & $p=0.98$ & & $p=0.79$ & & $p=0.41$ & & $p=0.16$ \\
\hline$\geq 350$ & $30(17.8)$ & 1.0 & $25(16.9)$ & 1.0 & $36(21.4)$ & 1.0 & $7(3.9)$ & 1.0 \\
\hline$\leq 349$ & $10(18.2)$ & $1.02(0.54-1.96)$ & $8(18.6)$ & $1.10(0.54-2.26)$ & $9(16.4)$ & $1.10(0.54-2.26)$ & $3(5.2)$ & $1.32(0.35-4.95)$ \\
\hline Viral load & & $p=0.23$ & & $p=0.17$ & & $p=0.39$ & & $p=0.008$ \\
\hline$\leq 999$ & $24(15.9)$ & 1.0 & $19(14.4)$ & 1.0 & $33(16.9)$ & 1.0 & $3(1.9)$ & 1.0 \\
\hline$\geq 1000$ & $16(22.5)$ & $1.42(0.00-2.50)$ & $13(22.4)$ & $1.56(0.83-2.94)$ & $12(21.9)$ & $0.77(0.43-1.41)$ & $7(9.3)$ & $4.98(1.32-18.7)$ \\
\hline Antirretroviral & & $p=0.29$ & & $p=0.09$ & & $p=0.13$ & & $p=0.003$ \\
\hline No ARV & $7(16.7)$ & 1.0 & $10(32.3)$ & 1.0 & $10(24.4)$ & 1.0 & $6(13.6)$ & $12.9(1.61-104.3)$ \\
\hline Biovir e Nelfinavir & $12(12.8)$ & $0.77(0.32-1.81)$ & $9(12.2)$ & $0.38(0.17-0.84)$ & $13(13.8)$ & $0.57(0.27-1.19)$ & $3(3.2)$ & $3.00(0.32-28.3)$ \\
\hline Biovir e Kaletra & $20(23.8)$ & $1.43(0.60-3.11)$ & $18(22.0)$ & $0.68(0.35-1.31)$ & $22(26.2)$ & $1.07(0.56-2.05)$ & $1(1.1)$ & 1.0 \\
\hline Other ARV & $3(18.8)$ & $1.13(0.33-3.83)$ & $2(12.3)$ & $0.41(0.10-1.66)$ & $5(31.3)$ & $1.28(0.52-3.17)$ & $0(0.0)$ & ---- \\
\hline Time of use of ARV & & $p=0.18$ & & $p=0.01$ & & $p=0.99$ & & $p=0.001$ \\
\hline$\leq 9$ weeks & $8(12.3)$ & 1.0 & $16(22.5)$ & 1.0 & $14(21.9)$ & 1.0 & $10(15.2)$ & 1.0 \\
\hline$\geq 10$ weeks & $29(19.9)$ & $1.61(0.78-3.34)$ & $19(15.9)$ & $0.47(0.26-1.66)$ & $32(21.9)$ & $1.0(0.58-1.75)$ & $0(0.0)$ & ---- \\
\hline
\end{tabular}


BARRAL, M.F.M.; OLIVEIRA, G.R.; LOBATO, R.C.; MENDOZA-SASSI, R.A.; MARTíNEZ, A.M.B. \& GONÇALVES, C.V. - Risk factors of HIV-1 vertical transmission (VT) and the influence of antiretroviral therapy (ART) in pregnancy outcome. Rev. Inst. Med. Trop. Sao Paulo, 56(2): 133-8, 2014.

Table 2

Adjusted analysis for unfavorable pregnancy outcome factors associated with HIV-infected women

\begin{tabular}{|c|c|c|c|}
\hline Outcome & Variable & Prevalence Ratio $\left({ }_{95 \%} \mathrm{CI}\right)$ & $p$-value \\
\hline Low birth weight $(\leq 2500 \mathrm{~g})$ & $\begin{array}{l}\text { Start of prenatal care } \\
1^{\text {st }} \text { trimester } \\
2^{\text {nd }} \text { trimester } \\
3^{\text {rd }} \text { trimester }\end{array}$ & $\begin{array}{l}1.0 \\
0.98(0.92-1.05) \\
1.07(1.01-1.14)\end{array}$ & 0.005 \\
\hline Delivery $\leq \mathbf{3 7}$ weeks & $\begin{array}{l}\text { Number of visits } \\
\geq 6 \text { visits } \\
\leq 5 \text { visits }\end{array}$ & $\begin{array}{l}1.0 \\
1.08(1.02-1.15)\end{array}$ & 0.013 \\
\hline HIV Vertical Transmission & $\begin{array}{l}\text { Prenatal care location } \\
\text { University Hospital } \\
\text { Other facilities } \\
\text { No prenatal care } \\
\text { Antirretroviral } \\
\text { No ARV } \\
\text { Biovir and Nelfinavir } \\
\text { Biovir and Kaletra } \\
\text { Other ARV }\end{array}$ & $\begin{array}{l}1.0 \\
7.61(1.04-55.57) \\
2.31(0.21-24.75)\end{array}$ & 0.041 \\
\hline
\end{tabular}

to ARV showed anemia, nausea, vomiting, hyperglycemia and elevated aminotransferase $\mathrm{e}^{1,18}$.

Most studies showed that the use of Biovir @during pregnancy has not been associated with an increased risk of teratogenicity ${ }^{4,26}$, low birth weight, smaller head circumference, cognitive dysfunction and preterm delivery ${ }^{1,4,17,22,28}$. However, research shows that the use of protease inhibitors (Nelfinavir ${ }^{\circledR}$ and Kaletra ${ }^{\circledR}$ ) could be associated to an increased risk of preterm birth ${ }^{11,19}$, although no association with low birth weight and lower Apgar score was found ${ }^{18,26,27,28,29}$.

In the bivariate analysis no significance was found between low birth weight and preterm birth and the other variables. After multivariate analysis, women who started prenatal care in the third trimester had a $7 \%$ higher risk of having infants with low birth weight. Likewise, pregnant women who had five or less visits had an increased risk of $8 \%$ for delivering before 37 weeks of gestation. In accordance to other published studies ${ }^{6,1,12,18,23}$ this research found no negative association of ART and low birth weight or prematurity.

Highest prevalence of preterm delivery and low birth weight has been associated with elective cesarean section ${ }^{9,12,13,20}$. Studies show that the current indication for elective cesarean, although decreasing the risk of transmission, may increase the prevalence of preterm births when performed before 38 weeks ${ }^{11,13,14,22}$. In our study the prevalence of delivery with less than 37 weeks was $22.8 \%$ among women undergoing cesarean section and $18.5 \%$ among women who gave birth vaginally. The high prevalence of caesarean section in this study is related to maternal viral load greater than or equal to 1000 copies/mL (32.1\%) or your ignorance after the $34^{\text {th }}$ week $(11.1 \%)$. We emphasize the importance of accurate assessment of gestational age (GA) with a first trimester ultrasound and date of last menstrual period compatible (LMP), when it is necessary to indicate elective cesarean section in this group.
In this study, the use of ART showed no association with a low score in the $5^{\text {th }}$ minute Apgar. YOSHIMOTO et al. $(2005)^{29}$, investigating the clinical and laboratory evolution of neonates from HIV-infected mothers, reported no relation between Apgar score and presence of HIV. Other studies in Brazil showed that the Apgar score in newborns of mothers with HIV was higher than seven in the first and fifth minute, not being related with the HIV infection. Values less than seven are associated with unfavorable outcomes during childbirth, especially neonatal asphyxia $^{16,24,30}$.

HIV MTCT rate in this study was 3.8\%. Among the factors that influenced HIV transmission are prenatal care outside the HIV service and non-use of combined ARV. After multivariate analysis, a 7-fold risk of transmitting HIV to the newborns was observed when women received prenatal care outside the reference service (HU-FURG). Probably the women who received prenatal care outside the reference service (HU-FURG) did not use or started using ARVs late. A fact that may have influenced a higher viral load in these women at greater risk and consequent VT. The Brazilian government has guidelines for the management of pregnant women with HIV, which emphasize the importance of early referral of pregnant women to a reference service ${ }^{2}$. Another factor that influenced MTCT was the ART, women who used Biovir $^{\circledR}$ and Kaletra ${ }^{\circledR}$ during pregnancy had $91 \%$ less risk of transmitting HIV to the neonates when compared with women who did not use ARV. Already using Biovir ${ }^{\circledR}$ and Nelfinavir ${ }^{\circledR}$ reduced the risk of MTCT by $88 \%$ compared to not using ARVs. TORNATORE et al. $(2010)^{23}$ in the same city demonstrated that the use of ARV during pregnancy lowers the risk of VT by $68 \%$.

The association between quality of prenatal care and pregnancy outcome is well established ${ }^{21}$. This study demonstrated that pregnant women with HIV, having adequate care, are susceptible to the very same factors that affect pregnancy outcomes in non-HIV women. Therefore, a 
BARRAL, M.F.M.; OLIVEIRA, G.R.; LOBATO, R.C.; MENDOZA-SASSI, R.A.; MARTÍNEZ, A.M.B. \& GONÇALVES, C.V. - Risk factors of HIV-1 vertical transmission (VT) and the influence of antiretroviral therapy (ART) in pregnancy outcome. Rev. Inst. Med. Trop. Sao Paulo, 56(2): 133-8, 2014.

proper prenatal care and initiation in the first trimester of pregnancy are crucial for avoiding risk associated with an unfavorable outcome. The rate of mother to child transmission of HIV becomes almost zero when these appropriate measures are taken. Despite the possible risks of using ARV by the mother during pregnancy, the benefits to the newborn are compensatory and its use did not influence the outcome of pregnancy. Undesirable outcomes (birth weight $\leq 2500 \mathrm{~g}$, Apgar score $\leq 7$ in the fifth minute, delivery $\leq 37$ weeks and HIV MTCT) seem to be related to the realization of inadequate prenatal care and maternal behavior. More research on the subject is essential, including studies analyzing long term effects in children who were exposed to ARV during pregnancy.

\section{RESUMO}

\section{Fatores de risco para a transmissão vertical do HIV-1 e a influência da terapia antirretroviral (ARV) no desfecho gestacional}

Na ausência de intervenção, as taxas de transmissão vertical do HIV podem variar de $15-45 \%$. Com a inserção dos antirretrovirais durante a gestação e a escolha da via de parto estas taxas chegam a menos de $2 \%$. No entanto o uso de ARV na gestação tem gerado várias duvidas quanto aos efeitos adversos causados ao desfecho gestacional e ao neonato. Este estudo objetiva analisar os fatores de risco da transmissão vertical do HIV-1 em gestantes soropositivas atendidas na cidade do Rio Grande e a influência do uso do ARV no desfecho gestacional. Entre as 262 gestantes estudadas a taxa de transmissão vertical do HIV encontrada foi de $3,8 \%$. Em relação à TV, foi observado menor risco de transmissão quando esta havia feito uso de antirretrovirais e o pré-natal era realizado no serviço de referência. Entretanto, o uso de ARV não influenciou negativamente o desfecho gestacional. No entanto, o inicio do pré-natal após o primeiro trimestre teve influencia sobre o baixo peso ao nascer, assim como a realização de menos de seis consultas aumentou o risco de prematuridade. Portanto, os fatores de risco analisados neste estudo parecem estar relacionados à realização não adequada do pré-natal e ao comportamento materno.

\section{REFERENCES}

1. Areechokchai D, Bowonwatanuwong C, Phonrat B, Pitisuttithum P, Maeka-A-Nantawa W. Pregnancy outcomes among HIV-infected women undergoing antiretroviral therapy. Open AIDS J. 2009;3:8-13.

2. Brasil. Ministério da Saúde. Secretaria de Vigilância em Saúde. Programa Nacional de DST e Aids. Recomendações para profilaxia da transmissão vertical do HIV e terapia antirretroviral em gestantes. Brasília: Ministério da Saúde; 2010.

3. Brasil. Ministério da Saúde. Boletim epidemiológico AIDS e DST. Brasília: Ministério da Saúde; 2011.

4. Brogly S, Abzug M, Watts DH, Cunningham CK, Williams PL, Oleske J, et al. Birth defects among children born to HIV-infected women: pediatric AIDS clinical trials protocols 219 and 219C. Pediatr Infect Dis J. 2010;29:721-7.

5. Cecchini D, Martinez M, Astarita V, Nieto C, Giesolauro R, Rodriguez C. Prevención de la transmisión vertical del VIH-1 en un hospital público de complejidad terciaria de Buenos Aires, Argentina. Rev Panam Salud Publica. 2011;30:189-95.

6. Cooper E, Charurat M, Mofenson L, Hanson IC, Pitt J, Diaz C, et al. Combination antiretroviral strategies for the treatment of pregnant HIV-1-infected women and prevention of perinatal HIV-1 transmission. J Acquir Immune Defic Syndr 2002;29:484-94
7. El Beitune P, Duarte G, Quintana S, Figueiró-Filho E, Marcolin AC, Abduch R Antiretroviral therapy during pregnancy and early neonatal life: consequences for HIV-exposed, uninfected children. Braz J Infect Dis. 2004;8:140-50.

8. Ferreira C, Ribeiro D, Oliveira EC, Barbosa MJ, Simão MB, Pinto VM. O desafio da redução da transmissão vertical do HIV e da sífilis no Brasil. DST - J Bras Doenças Sex Transm. 2007;19:184-6.

9. Fuchs K, Wapner R. Elective cesarean section and induction and their impact on late preterm births. Clin Perinatol. 2006;33:793-801.

10. Kissin DM, Mandel MG, Akatova N, Belyakov NA, Rakhmanova AG, Voronin EE, et al. Five-year trends in epidemiology and prevention of mother-to-child HIV transmission, S. Petersburg, Russia: results from perinatal HIV surveillance. BMC Infect Dis. 2011;11:292.

11. Kourtis AP, Schmid CH, Jamieson DJ, Lau J. Use of antiretroviral therapy in pregnant HIV-infected women and the risk of premature delivery: a meta-analysis. AIDS. 2007;21:607-15.

12. Lisonkova S, Hutcheon JA, Joseph KS. Temporal trends in neonatal outcomes following iatrogenic preterm delivery. BMC Pregnancy Childbirth. 2011;25:11-39.

13. Lopez M, Figueras F, Hernandez S, Lonca M, Garcia R, Palacio M, et al. Association of HIV infection with spontaneous and iatrogenic preterm delivery: effect of HAART. AIDS. 2012;26:37-43

14. Machado LS. Cesarean section in morbidly obese parturients: practical implications and complications. N Am J Med Sci. 2012;4:13-8.

15. Marazzi MC, Palombi L, Nielsen-Saines K, Haswell J, Zimba I, Magid N, et al. Extended antenatal use of triple antiretroviral therapy for prevention of mother-tochild transmission of HIV-1 correlates with favorable pregnancy outcomes. AIDS. $2011 ; 25: 1611-8$

16. Oliveira MIV, Bezerra MGA, Bezerra Filho JG, Bezerra JP, Oliveira R, Feitosa RFG Puérperas com vírus humano da imunodeficiência positivo (HIV+) e as condições de nascimento de seus recém-nascidos. Enfermería Global. 2012;28:439-52.

17. Patel K, Shapiro DE, Brogly SB, Livingston EG, Stek AM, Bardeguez AD, et al. Prenatal protease inhibitor use and risk of preterm birth among HIV-infected women initiating antiretrovirals drugs during pregnancy. J Infect Dis. 2010;201:1035-44.

18. Pilotto JH, Velasque L, Freidman RK, Moreira RI, Veloso VG, Grinsztejn B, et al. Maternal outcomes after highly active antiretroviral therapy for the prevention of mother-tochild transmission in HIV-infected women in Brazil. Antivir Ther. 2011;16:349-56.

19. Ravizza M, Martinelli P, Bucceri A, Fiore S, Alberico S, Tamburrini E, et al. Treatment with protease inhibitors and coinfection with hepatitis $C$ virus are independent predictors of preterm delivery in HIV-infected pregnant women. J Infect Dis. 2007;195:913-4

20. Reddy UM, Ko CN, Raju TN, Willinger M. Delivery indications at late-preterm gestations and infant mortality rates in the United States. Pediatrics. 2009;124:234-40.

21. Santos IS, Matijasevich A, Silveira MF, Sclowitz IK, Barros AJ, Victora CG, et al. Associated factors and consequences of late preterm births: results from the 2004 Pelotas birth cohort. Paediatr Perinat Epidemiol. 2008;22:350-9.

22. Schulte J, Dominguez K, Sukalac T, Bohannon B, Fowler M. Declines in low birth weight and preterm birth among infants who were born to HIV-infected women during an era of increased use of maternal antiretroviral drugs: pediatric spectrum of HIV disease, 1989-2004. Pediatrics. 2007;119:900-6.

23. Tornatore M, Gonçalves CV, Mendoza-Sassi RA, Silveira JM, D’Avila NE, Maas CG, et al. HIV-1 vertical transmission in Rio Grande, Southern Brazil. Int J STD AIDS 2010;21:351-5 
BARRAL, M.F.M.; OLIVEIRA, G.R.; LOBATO, R.C.; MENDOZA-SASSI, R.A.; MARTíNEZ, A.M.B. \& GONÇALVES, C.V. - Risk factors of HIV-1 vertical transmission (VT) and the influence of antiretroviral therapy (ART) in pregnancy outcome. Rev. Inst. Med. Trop. Sao Paulo, 56(2): 133-8, 2014.

24. Vasconcelos AL, Hamann EM. Por que o Brasil ainda registra elevados coeficientes de transmissão vertical do HIV? Uma avaliação da qualidade da assistência prestada a gestantes/parturientes infectadas pelo HIV e seus recém-nascidos. Rev Bras Saúde Mater Infant. 2005;5:483-92

25. Volmink J, Siegfried N, van der Merwe L, Brocklehurst P. Antiretrovirals for reducing the risk of mother-to-child transmission of HIV infection. Cochrane Database Syst Rev. 2007;(1):CD003510.

26. Watts DH, Huang S, Culnane M, Kaiser KA, Scheuerle A, Mofenson L, et al. Birth defects among a cohort of infants born to HIV-infected women on antiretroviral medication. J Perinat Med. 2011;39:163-70.

27. WHO - World Health Organization. Mother-to-child transmission of HIV. (cited 2012 Nov). Available from http://www.who.int/hiv/topics/mtct/en/

28. Williams PL, Marino M, Malee K, Brogly S, Hughes MD, Mofenson LM. Neurodevelopment and in utero antiretroviral exposure of HIV-exposed uninfected infants. Pediatrics. 2010;125:250-60.

29. Yoshimoto C, Diniz EM, Vaz FA. Evolução clínica e laboratorial de recém-nascidos de mães HIV positivas. Rev Assoc Med Bras. 2005;51:100-5.

30. Zorzi PM, Madi JM, Rombaldi RL, Araújo BF, Zatti H, Madi SR, et al. Fatores perinatais associados a recém-nascidos de termo com $\mathrm{pH}<7,1$ na artéria umbilical e índice de Apgar $<7,0$ no $5^{\circ}$ minuto. Rev Bras Ginecol Obstet. 2012;34:381-5.

Received: 20 May 2013

Accepted: 2 September 2013 